\title{
4 \\ A new normal? The changing future of nuclear energy in China
}

\author{
M. V. Ramana and Amy King
}

\section{Abstract}

In recent years, China has reduced its goal for expanding nuclear power capacity, from a target of 70 gigawatts (GW) by 2020 issued in 2009 to just 58 GW by 2020 issued in 2016. This chapter argues that this decline in targets stems from three key factors. The first factor is China's transition to a relatively low-growth economy, which has led to correspondingly lower levels of growth in demand for energy and electricity. Given China's new lowgrowth economic environment, we argue that the need for rapid increases in nuclear power targets will likely become a thing of the past. The second factor is the set of policy changes adopted by the Chinese government following the March 2011 Fukushima Daiichi nuclear disaster in Japan. Since the Fukushima disaster, China's State Council has stopped plans for constructing inland nuclear reactors and restricted reactor construction to modern (third-generation) designs. The third factor is government responsiveness to public opposition to the siting of nuclear facilities near population centres. Collectively, these factors are likely to lead to a decline in the growth rate of nuclear power in China. 


\section{Introduction}

In March 2016, China's National People's Congress endorsed its draft 13th Five Year Plan (2016-20), which set China the goal of developing 58 gigawatts $(\mathrm{GW})$ of operating nuclear capacity by 2020 , with another $30 \mathrm{GW}$ to be under construction by then. At first glance, this goal appears ambitious, for it represents a doubling of China's current nuclear capacity of 29 GW (as of May 2016, according to the International Atomic Energy Agency's (IAEA) Power Reactor Information System (PRIS) database). Nevertheless, a closer look at this target, and the history behind it, tells a somewhat different story. Back in 2002, China's draft short- and medium-term plan for nuclear expansion called for China to build 40 GW of nuclear capacity by 2020. In 2009, the target figure was increased dramatically to $70 \mathrm{GW}$ of nuclear capacity by 2020 . Although large, there was an expectation that this $70 \mathrm{GW}$ target would be met easily; for example, the director of science and technology at the China National Nuclear Corporation (CNNC) - one of the major state-owned enterprises (SOEs) involved in constructing and operating nuclear power plants—stated that 'reaching $70 \mathrm{GW}$ before 2020 will not be a big problem' (Stanway 2009). So what happened between the announcement in 2009 of the $70 \mathrm{GW}$ target and the announcement in 2016 of the lower $58 \mathrm{GW}$ target? In this chapter, we argue that this decline in targets results in part from the policy changes and government responsiveness to public concerns following the March 2011 Fukushima Daiichi nuclear disaster, and in part from China's transition to a relatively low-growth economy with correspondingly lower levels of growth in demand for energy and electricity.

The first factor that affects nuclear power targets is the growth rate for electricity demand. Electricity demand has flattened in China as the country's economy has started to undergo structural changes, from being an economy primarily focused on export-led industrial production to one oriented towards the service sector and domestic consumption. This shift has led to what many have termed the 'new normal' (Green and Stern 2016; Hu 2015; Levi, Economy, and Rediker 2016), with a corresponding decrease in energy and electricity demand. The average amount of electricity produced by different kinds of power plants has also declined. Taken as a whole, power plants operated for 349 fewer hours in 2015 as compared to 2014; specifically, thermal plants operated 410 hours less than they did in 2014, whereas the number of hours that the average nuclear power plant fed electricity into the grid declined by 
437 hours, the largest decline among all power plants (Wong 2016a). Some expect the decline to be a long-term trend (Ying 2016). Under these circumstances, it is likely that the need for rapid increases in nuclear power targets will become a thing of the past.

The second factor that has changed Chinese nuclear planning is the Fukushima disaster, which had an immediate dampening effect on the Chinese government's push to rapidly expand nuclear power. Five days after the accident at Fukushima started, the State Council, China's chief administrative authority, stated:

We will temporarily suspend approval for nuclear power projects, including those that have already begun preliminary work, before nuclear safety regulations are approved ... Safety is our top priority in developing nuclear power plants (Bristow 2011).

Since then, the Chinese government has verbally committed to ensuring nuclear safety, and has introduced a number of operational measures aimed at lowering the risk of accidents (as described in detail in King and Ramana 2015). Over and above these, the State Council made two important decisions: (1) to restrict construction of nuclear reactors in inland areas, and (2) to restrict the choice of reactor designs for construction to only the so-called 'third-generation' designs. At the time of writing, the State Council had also issued a third draft decision that may further restrict the expansion of nuclear power in China: namely, to require all nuclear developers to solicit local public opinion and undertake local 'social stability' impact reports before proceeding with new projects.

As we have argued elsewhere (King and Ramana 2015), these decisions, especially the one to stop construction in inland areas, are being shaped and contested by China’s economic plans, national atmospheric pollution reduction plans, corporate economic interests, public opposition to nuclear power, and local government bureaucratic pressure. More generally, China's choices on nuclear power are shaped by China's system of governance, which affords a relatively high degree of political power to local authorities and SOEs, which dominate China's nuclear power sector (Xu 2008, 2014; Ramana and Saikawa 2011). Whether or not the decisions made by Chinese central authorities to enhance nuclear safety in the aftermath of Fukushima continue to be upheld in the future will be dependent on the interactions between, and priorities of, these multiple actors. Nevertheless, we argue, the two decisions made in 2011-12 have led to a lowering of the nuclear installation target for 2020. Had there not 
been a shift in the pattern of the economy, the post-Fukushima decisions might have only resulted in a temporary change in policy. But when combined with the shift in the nature of China's energy demand, and the government's growing concern about public opposition to nuclear energy, we anticipate that these changes in policy will shape deeply the future of Chinese nuclear capacity.

In the remainder of this chapter, we first elaborate on the decline in energy growth rates and their implications for nuclear power targets. Then we discuss, in turn, the ban on inland reactor construction, the implications of the State Council's restriction on the type of reactor designs that may be installed, and the implications of the government's responsiveness to negative public attitudes to nuclear power, such as its 2016 decision to cancel the building of a nuclear processing plant in Lianyungang, Jiangsu province, in the face of public protests. We conclude with the overall inferences of our arguments and some remarks on the political struggles that might shape the future of nuclear power in China.

\section{The changing nature of energy demand in China}

In the last couple of years, there have been significant shifts in China's economic growth rates and development strategy. After more than a decade of rapid growth in China's energy-intensive heavy industry sector between 2000 and 2013, China's economy has now begun transitioning towards less energy-intensive sectors such as services and advanced technology (Green and Stern 2016). This shift is intentional: the country's leadership has been trying deliberately to steer China away from an overwhelming focus on exports towards exploiting domestic demand for products, partly in the expectation that this shift will reduce the environmental impacts of large-scale industrial manufacture. Alongside this, there has been an emphasis on improving energy efficiency. For example, for the year 2016, the China National Energy Administration (CNEA) announced a target of reducing energy consumption per unit of gross domestic product (GDP) by at least 3.4 per cent (Xinhua 2016). All of these factors have contributed to a 'new normal', which has resulted in lower growth rates in energy consumption. Compared with energy consumption growth rates of around 8 per cent per year from 2000 to 2013, Chinass total energy consumption in 2014 grew by just 
2.2 per cent, and by just 0.5 per cent in 2015 (Green and Stern 2016: 5; China Electricity Council 2016). Furthermore, as China's economy continues to transition away from heavy industry sectors such as steel and cement, it is estimated that energy consumption will grow by just 1.8 per cent per year out to 2025 (Green and Stern 2016: 10). Another estimate is from the oil and gas firm Exxon, which has forecast that China's annual energy demand will grow by just 2.2 per cent per year out to 2025 , and predicts that 'the country's energy demand would plateau around 2030' (Groden 2016). To be sure, these estimates are for energy demand growth rather than electricity demand, which might be higher because of continued urbanisation and other trends. Nevertheless, if the energy demand growth rate has fallen by a factor of four, it is only to be expected that the electricity demand growth rate will decline as well, even if it may not be as precipitous.

There is a slow-growing realisation that these changes in the economy will impact electricity generation plans. In the words of Zhou Dadi, a senior research fellow with the Energy Research Institute of the National Development and Reform Commission (NDRC):

A 'new normal' has been unfolding in China's power sector. It's marked by weakening demand and a contraction in output resulting from the industrial restructuring. We have been used to seeing annual electricity consumption increase by $8 \%$ or more but it's quite a different situation now (quoted in Ying 2016).

Analysts Jiang Lin, Gang He, and Alexandria Yuan (2016) used 20 years of provincial data on GDP and electricity consumption to deduce a plateauing effect of electricity consumption in the richest provinces, as the electricity demand saturates and the economy develops and moves to a more service-based economy. Their evidence suggests the emergence of a 'new normal relationship' for electricity use. Therefore, they warn:

If the power system planning approach is not responsive to these emerging trends, there is a significant chance of overbuilding the power capacity in China, with hundreds of billions of dollars of investment potentially stuck as stranded assets (Lin, He, and Yuan 2016: 52).

Indeed, 'if all the coal power projects submitted for Environmental Impact Assessment (EIA) approval were put into operation in 2020' the available capacity could exceed the demand by $200 \mathrm{GW}$ or more 
(Yuan et al. 2016: 136). This should not be surprising since there are other areas where China seems to be building overcapacity; for example, in what have been termed 'ghost cities' (Chinadialogue 2015).

Excess capacity is not uniformly distributed, with some regions projected to have much greater mismatch than others (in part because of existing regional variations in power supply and demand). This has led to the imposition of cutbacks in electricity production from nuclear plants in specific provinces. Provinces that have seen nuclear operators being asked to cut back are Fujian, Hainan, and, most dramatically, Liaoning, 'where China General Nuclear's Hongyanhe nuclear plant has faced major curtailments' (Wong 2016b: 4). Looking ahead, if even some of the coal plants that are being planned are actually commissioned, then the situation would be further detrimental to the expansion of nuclear power since both coal and nuclear plants can be considered as competing for operation as a baseload supplier of electricity.

China's transitioning economy and the shift to lower rates of economic growth and energy consumption mean that the central government faces considerably less pressure to rapidly roll-out new nuclear power plants to meet the ambitious nuclear growth rates stipulated between 2002 and 2011. The impact of this lowered pressure is already apparent: provincial governments and those in the nuclear industry seem to be less persuasive when pushing to restart construction of inland nuclear power plants, as we shall see in the next section.

\section{The inland construction ban and the consequent shortage of sites}

One important constraint on nuclear expansion in China is the choice of sites. Prior to the Fukushima accident, China had plans for a vast expansion of nuclear power stations, not only at coastal sites where reactors had traditionally been sited, but also at new inland sites (Du 2010). Since Fukushima, however, the Chinese government has prohibited the construction of all inland reactors, with the State Council placing a ban on inland reactor construction for the duration of the 12th Five Year Plan (2011-15). The decision to ban inland reactors was made for safety reasons: all nuclear reactors need large quantities of water to cool their radioactive cores and lack of adequate cooling water could cause a severe accident. In the case of potential inland power plants, the only 
sources of water are rivers and lakes, both of which also serve many other needs, including water for irrigation and household consumption. Inland nuclear power plants therefore pose far higher risks to nearby water sources and people dependent on these resources than comparable coastal plants. As we describe below, ever since the decision was made in 2012, there has been much pressure from vested interests to lift this ban. But so far the central government has not succumbed to that pressure and the 13th Five Year Plan put off construction of inland reactors until at least 2020 (Yu 2016b).

These safety concerns have been echoed by Chinese researchers. One prominent critic of inland nuclear reactors, He Zuoxiu, is a leading theoretical physicist, who worked on China's first nuclear bomb. He has warned against building 'any nuclear power plant in the inland regions' due to his concerns about problems with water supply, and his calculation that a reactor accident in China by 2030 is 'highly probable' (He 2013; Xuyang 2012). Another key figure has been Wang Yinan, a policy researcher from a State Council subsidiary institute, who has questioned the construction of inland nuclear power plants on safety grounds (Yu 2016b). Other prominent critics include government officials from provinces that border potential inland nuclear projects. A good illustration of this is the Pengze nuclear power project in Jiangxi province, which was originally slated to host two AP1000 reactors (Wang 2009).

Pengze, along with Xianning in Hubei province and Taohuajiang in Hunan province, was among the first inland nuclear power projects proposed in the late 2000s. In 2010, Chinese nuclear officials expected that these sites would be 'ready for construction' by the end of the year (Zheng and Wu 2010). However, the Fukushima accident prompted strong opposition to the Pengze reactor, particularly in neighbouring Anhui province (Cui 2012). The Pengze plant is sited alongside the Yangtze River, which is a vital water supply for farmers in Anhui (Hook 2012). In July 2011, four retired government officials in Anhui province submitted a petition to local and central government agencies listing various problems with the clearance given to the project and calling for its halting. These concerns eventually reached the government of Wangjiang county in Anhui province, which is downstream from the proposed Pengze site. The Wangjiang government opposed the project and publicly accused the Pengze project of 'falsifying its EIA report', expressed concern about the high local population density and the risk of earthquakes, and objected to Jiangxi province's failure to consult its provincial neighbours before deciding where to site the plant (Wen 2014). 
This individual case study points to the more general problem that conflicting interests can arise when making decisions about the siting of nuclear power plants (Aldrich 2008). The structure of benefits and risks is such that all of the economic gains from the nuclear power plant would accrue to the host province (Jiangxi), but accidents would also affect neighbouring provinces (such as Anhui) (Zhu 2014).

There are also very strong forces in China actively encouraging the resumption of inland construction, including local provincial and county-level governments who will host any future inland power plants, and the SOEs who will construct and manage the inland power plants. To understand these forces, consider the situation in Hunan, Hubei, and Jiangxi provinces where three inland nuclear power plants-Hunan's Taohuajiang power station, Hubei's Xianning Dafan power station, and Jiangxi's Pengze power station-were proposed prior to the Fukushima incident.

For the Hunan, Hubei, and Jiangxi provincial governments, the desire to restart planning for inland reactors and their eventual construction primarily stems from economic interests. Each of the provincial governments has a stake in the projects; for instance, the Hunan government holds a direct 5 per cent stake in the Taohuajiang project, while the Jiangxi government holds a more indirect stake of 40 per cent through its financial backing of a provincial energy firm, which has invested in the site (Yu 2015).

Provincial governments also stand to benefit economically once the reactors come into service, and local SOEs have taken great pains to remind provincial governments of these benefits. For instance, the general manager of the Hunan Taohuajiang Nuclear Power Company, Zheng Yanguo, told reporters in September 2014 that an investment of 70 billion yuan (US\$11 billion) in the Taohuajiang nuclear power plant would return GDP growth of over 100 billion yuan to Hunan province, and generate annual tax income of around 15 billion yuan (Zhongguo Jinggong Bao 2014). These kinds of claims have led the Hunan Taohuajiang Nuclear Power Company, the Hunan provincial government, and the local Taojiang county government (where the Taohuajiang site is located) to exert joint pressure on the central government in Beijing to approve inland reactors, and to use the media and other public means of communication to raise expectations that inland reactors will soon be built (Xu 2014: 24; Securities Daily 2015). For instance, in September 2014, 
the Taohuajiang general manager informed reporters that 'preparatory work for the Taohuajiang nuclear power station will commence in 2016, in accordance with the schedule' (Zhongguo Jinggong Bao 2014). Likewise, at the March 2015 National Party Congress, delegations from Hunan and Hubei provinces called upon the central government to restart construction of inland power projects at the beginning of the 13th Five Year Plan, and reminded the central government that the Taohuajiang, Dafan, and Pengze projects were ready for construction (Zhongguo Hedian Wang 2015). Furthermore, there were also signs that new inland sites were being prepared in anticipation of a lifting of the ban. In July 2014, it was reported that the China General Nuclear Power Corporation (CGNPC) had 'agreed to invest 38 billion yuan ( $\$ 6.1$ billion) in two nuclear power plants in southwest China’s Guizhou Province' (Xinhua 2014). Prior to the Fukushima nuclear disaster, there were no plans to construct a nuclear plant in that province (WNA 2010).

Provincial governments and those in the nuclear industry have also attempted to use the State Council's development targets as a way to pressure the central government to lift the ban on inland reactors. This is because there are few coastal sites available for new nuclear plants; raising nuclear capacity would thus require China to find new sites inland. According to a 2015 analysis in Nuclear Intelligence Weekly, a trade journal:

The Mid-Long Term Nuclear Development Plan (2011-2020) ratified by the State Council in 2012 envisions 58,000 MW [megawatts] of operational nuclear capacity at the end of 2020, with 30,000 MW under construction for a total of $88,000 \mathrm{MW}$. This means that within the next six years, China would have to start six to seven 1,000 MW units on average each year, representing a combined capacity of roughly 40,000 MW. This can only be achieved by adding inland sites to the mix since available coastal sites are becoming fewer and fewer. Indeed, State Council data published back in 2007 listed more than 40 sites reserved in China for future nuclear power projects-and at least 31 of them are inland (Yu 2015). ${ }^{1}$

Subsequently, provincial governments and those in the nuclear sector have used these older targets for their lobbying purposes. For example, a feasibility study produced by the Hunan Taohuajiang Nuclear Power

1 Similar nuclear energy targets can also be found in the Nengyuan hangye jiaqiang daqi wuran fangzhi gongzuo fang'an [Energy industry work plan for strengthening the prevention and control of atmospheric pollution], which was jointly issued by the NDRC, Bureau of Energy, and Ministry of Environmental Protection in May 2014. 
Company stated that due to the limitation in sites, there was a 'large gap' in China's ability to meet the central government's nuclear power targets with the power stations currently installed and under construction (Zhongguo Jinggong Bao 2014). Similarly, during the March 2016 Chinese People's Political Consultative Conference, the chairman of the CGNPC, $\mathrm{He} \mathrm{Yu,} \mathrm{told} \mathrm{reporters} \mathrm{that} \mathrm{the} \mathrm{scale} \mathrm{of} \mathrm{China's} \mathrm{current} \mathrm{nuclear}$ power is 'still too small' to achieve China's economic development goals (L. Wang 2016).

Despite this intense pressure, and the limited number of coastal sites still available to build new plants, the central government has so far not reversed its ban on inland nuclear construction. In December 2014, the State Council released its Energy Development Strategy Action Plan (2014-20) (hereafter the 'Action Plan'). A State Council circular discussing the Action Plan indicated that inland nuclear power still required further research and proof of safety (CNEA 2014b). Media reports around the time of the Action Plan's release also noted that 'there is still a lot of controversy around inland nuclear power in China', while officials from the CNEA told reporters that inland nuclear power 'must be proved and proved again' (CNEA 2014a).

Moreover, in March 2016, the NDRC deputy director and director of the CNEA, Nur Bekri, issued a clear retort to provincial governments and those in the nuclear industry who have used the central government's targets to lobby for the development of inland plants. Bekri stated that 'coastal nuclear power plants are sufficient to realize the nuclear power development targets [of $58 \mathrm{GW}$ ] contained in the 13th Five Year Plan' (Xie 2016). He went on to say that 'there is no timetable for restarting' inland nuclear power plants, and that the CNEA would recommend restarting inland projects only if safety could be 'absolutely guaranteed' (Xie 2016). This unusually strong language-strictly speaking, an absolute guarantee of safety is impossible-suggests two things: first, there are still significant political barriers to constructing nuclear plants away from the coast, and second, lower rates of energy demand make the NDRC and State Council better able to resist local government and industry pressure to restart inland construction. The second point is underscored by examining the regional distribution of the excess coal power capacity discussed earlier. If all the proposed coal plants are commissioned in the two inland regional electric grids of China-the Northwest and the Central China gridsthen there would be 41,010 MW and 47,300 MW of excess capacity (Yuan et al. 2016: 142). 


\section{Problems with new reactor designs}

The second constraint that results from the policy changes decreed by the State Council after its 2011-12 review relates to the requirement that '[n] ewly constructed power units must comply with third-generation nuclear power technology safety standards' (Wen 2012). The problem this poses to rapid nuclear expansion is that third-generation nuclear reactors, namely the latest designs, cost more and have taken longer to construct, both in China and elsewhere in the world (Schneider et al. 2015).

Prior to the Fukushima disaster, Chinese nuclear officials and policymakers had identified the development of Generation III reactor technology as a key goal for the Chinese nuclear sector. Among the priority areas for research and development identified by the 'National Medium and Long-Term Science and Technology Plan (2006-2020)', issued by the government in 2005, was the development of indigenous 'advanced large-scale pressurized water reactors' (Mu 2010: 380). Despite these goals, however, China had yet to develop indigenous Generation III reactor technology at the time of the Fukushima disaster. In 2011, the 27 reactors then under construction in China included the following reactor models: CNP-600, CPR-1000, AP1000, and the European pressurised reactor (EPR) (WNA 2011). Of these, the two Chinese-designed reactors-the CNP-600 and CPR1000 - were classified as Generation II, and their safety was considered less reliable than European or US models. ${ }^{2}$ China's central government had mandated the setting up of a Chinese 'Nuclear Power Self-Reliance Program' to develop a domestic Generation III reactor using a modified Western design (in this case, the AP1000 reactor). In 2010, just one year before the Fukushima disaster, two academics from Tsinghua University observed that 'China has basically mastered the generation II of nuclear technology, but still lacks the R\&D required for generation IIP (Zhou and Zhang 2010: 4283, emphasis added). Therefore, it is clear that there was no indigenous capacity to come up with an independent Generation III design at the time of Fukushima.

2 The only reactors that were categorised as Generation III in 2010 were the AP1000, the advanced boiling water reactor (ABWR), the economic simplified boiling water reactor (ESBWR), the European pressurised reactor (EPR), and the water-water energetic reactor (VVER). Of these, the ESBWR had not received regulatory approval in 2010. 
Nevertheless, in the wake of the Fukushima accident, the Chinese nuclear industry moved quickly to reassure the public that the continued expansion of nuclear power in China would be safe because it would be based on Generation III reactors. Lu Qizhou, general manager of the China Power Investment Corporation, for example, pointed out that the 'reactors in the Japanese nuclear power plants, which have been affected by the massive quake, are Generation II reactors and have to rely on back-up electricity to power their cooling system in times of emergency', whereas the 'AP1000 nuclear power reactors, currently under construction in China's coastal areas and set to be promoted in its vast hinterland, are Generation III reactors and have built in safety features to overcome such a problem' (Xinhua 2011).

Comments such as those by Lu Qizhou led to a flurry of competitive activity in the Chinese nuclear industry. ${ }^{3}$ Because China did not yet have its own domestic Generation III capability, it needed to rely on imported Western models, such as the AP1000, if it wished to guarantee the use of Generation III technology. However, only one of the players in the Chinese nuclear power sector, the State Nuclear Power Technology Corporation (SNPTC), held government authority 'to sign contracts with foreign parties to receive ... 3rd generation nuclear power technology' (SNPTC 2011). Given the domestic expectation after Fukushima that only Generation III reactors would be permitted in new power stations, by May 2011—just three months after Fukushima—the SNPTC had convinced officials at Westinghouse Electric Company that Westinghouse was going to dominate the Chinese reactor market ( $\mathrm{Li}$ and Tranum 2011).

It did not take long for other players in the Chinese nuclear power sector to respond to this potential threat to their market share. Two of the other major players in the Chinese nuclear power sector, the CNNC and the CGNPC, responded by quickly producing their own reactor designs, which they described as being compliant with Generation III requirements.

In November 2011, the CGNPC announced that it had developed and held 'full intellectual property rights'-a key requirement for exports-over the newly designed ACPR1000, a reactor that it stated

3 News media also shared the impression that as 'China attaches more focus on the safety of nuclear technology, it is likely to adopt the third-generation AP 1000 technology developed by USbased Westinghouse Electric Co in its future plants' (Liu 2011). 
had incorporated the lessons of Fukushima in 'meeting the standards of international third-generation nuclear power technology' (Pan 2011). A few months later, at the third Asia Nuclear Power Summit in January 2012, the CNNC unveiled its own ACP1000 reactor (Zhou 2012). Adding to this menagerie is the Hualong One, a Generation III design jointly developed by the CNNC and the CGNPC; in 2014, the Hualong One design was certified by the National Nuclear Saftey Administration (Hore-Lacy 2014). There are questions about whether the Hualong One is one design or if there are two separate designs developed by the CNNC and the CGNPC respectively, both of which are marketed under the same name (Yu 2016a; Thomas 2017).

These questions notwithstanding, the Hualong One design is now being promoted enthusiastically outside China as its most advanced reactor and, in February 2015, the CNNC signed a contract with Argentina for the export of this design (World Nuclear News 2015). In March 2016, the CGNPC and the CNNC set up a 50-50 joint venture to promote the Hualong design in overseas markets (World Nuclear News 2016). The Chinese nuclear industry has also begun to exploit Chinese President $\mathrm{Xi}$ Jinping's new 'Belt and Road Initiative' as a way to further expand the overseas roll-out of the Hualong One. In March 2016, CNNC chairman Sun Qin ambitiously claimed that the Hualong One was expected to obtain 20-30 per cent market share of the more than 40 countries within the 'Belt and Road' region that were seeking to develop nuclear power (CNNC 2016).

The speed with which all these new reactor designs were rolled out by the CNNC and the CGNPC raises serious questions about whether these reactors actually meet Generation III safety requirements. While the CNNC and the CGNPC were certainly talking about developing Generation III designs prior to Fukushima, in part to improve their chances of entering the reactor export market, the real momentum for the development of the ACPR1000, the ACP1000, and the Hualong One came only after the Fukushima disaster in 2011 (World Nuclear News 2010). For the sake of comparison, the Westinghouse AP1000 reactor, which was approved for construction in the United States in February 2012 (Hargreaves 2012), received approval only after 19 revisions to its reactor design were examined by the US Nuclear Regulatory Commission (NRC) (2011). Furthermore, the AP1000 was itself a modification of the AP600, which had been certified by the US NRC 13 years earlier in 1999 after a 'ten-year, multi-million dollar effort by the NRC staff, 
the US Department of Energy, the Electric Power Research Institute and supporting utilities, Westinghouse, its subcontractors and partners' (Westinghouse Electric Company 2000).

The relatively short period of time taken by Chinese corporations to develop their Generation III reactors suggests that these new Chinese models may be Generation III in name only. Indeed, analysts who have followed the development of these new reactors report that they are merely 'enhanced versions of the current CPR-1000' (Hinze and Zhou 2012), the Generation II reactor that was being constructed en masse in China prior to Fukushima. Even though the Hualong One has been certified, observers see the design as being at an 'early stage'. ${ }^{4}$

To the extent that there has been construction of more advanced reactor designs (imported from France and the United States) in China, these projects have been afflicted with significant cost overruns and delays. The EPR units 1 and 2 being built at Taishan were originally scheduled to 'be commissioned at the end of 2013 and in autumn 2014' respectively, and France's Areva had hoped 'to have started work on more reactors' by then (Thibault 2010). Neither of these expectations were met. In January 2016, Taishan-1 underwent its cold functional test (Taishan Nuclear Power Joint Venture Co. 2016), a pre-operational step that has to be completed before any fuel is loaded into the reactor. In March 2016, CGNPC officials projected that Taishan-1 would start up in 2017 (Chaffee 2016).

China's experience in building Generation III AP1000 reactors at the Sanmen and Haiyang sites has also been fairly troubled, with significant delays, cost escalations, and the identification of safety concerns (Stanway 2014; Yap and Spegele 2015; Lok-to 2016). With these reactors, the main source of problems, although not the only one, has been the reactor coolant pumps that were supplied by US manufacturer Curtiss-Wright Corporation. The reactor coolant pump forces water to circulate through the reactor and transfer the heat generated by the fission reactions in the reactor core. Problems with the reactor coolant pumps could have serious safety consequences and Chinese nuclear officials have expressed concern in the past about these problems. In 2013, for example, a former vice president of the CNNC complained: 'Our state leaders have put a high priority on [nuclear safety] but companies executing projects do not seem to have the same level of understanding' ( $\mathrm{Ng} 2013)$. The result has

4 Personal communication, C. F. Yu, 9 March 2015. 
been a very long series of delays. As of January 2017, the expectation was that the four AP1000s will go into operation before the end of 2017 (World Nuclear News 2017). If this were to happen as hoped for, electricity generation from the AP1000s would take place four years after schedule.

The slower pace of construction has not only resulted in targets for nuclear generation being set back but also in higher costs. Estimates by China's Nuclear Energy Agency suggest that the cost of constructing Generation III reactors is significantly higher (US $\$ 2,300$ per kilowatt $(\mathrm{kW})$ for the AP1000) than Generation II reactors (US $\$ 1,750$ per $\mathrm{kW}$ for the CPR1000) (IEA/NEA 2010: 48). More recently, the Hualong One's deputy chief designer has estimated that the 'targeted construction cost of Hualong One ... when production was scaled up' will actually be US $\$ 2,500$ per $\mathrm{kW}$. Adding the caveat 'when production was scaled up' means, by implication, that the cost of early units will be significantly higher and that US $\$ 2,500$ per $\mathrm{kW}$ is only an aspirational goal for the future. And if China reproduces the pattern of cost increases and negative learning that has characterised nuclear plant construction in other countries (Boccard 2014; Grubler 2010; Koomey and Hultman 2007), the goal of US\$2,500 per $\mathrm{kW}$ may never be reached. Offering further evidence for the expected higher costs of Generation III reactors is another newspaper article that has claimed implicitly that the cost of the Hualong One is US $\$ 3,000$ per $\mathrm{kW}$ (Abe 2016).

The impact of this higher construction cost is that in the face of slower demand growth, it is possible that the Chinese government will choose to emphasise other, cheaper sources of energy over nuclear power. In particular, there is evidence of both rapidly increasing capacity of wind and solar energy, as well as declining costs of these sources. Thus, in comparison to the 2000-10 decade, one might expect that nuclear growth targets would be more modest.

\section{Public opinion shapes nuclear policy}

The third factor acting as a constraint on the roll-out of new nuclear power stations in China is the growing government responsiveness to public opposition to the siting of nuclear facilities. Since the Fukushima accident, there has been a significant increase in the Chinese public's perception of risk from nuclear facilities. Two surveys of residents living near the Tianwan nuclear power plant in Lianyungang, Jiangsu province, 
the closest nuclear plant to Fukushima, which were conducted in August 2008 and March-April 2011, found a dramatic decline in support for nuclear power (Huang et al. 2013). The percentage of respondents who agreed with the proposition 'Nuclear power should be used in our country' went down from 68 per cent to 32 per cent, and the fraction that agreed with the proposition 'We should quickly increase the number of nuclear power stations in China' declined from 40 per cent to 17 per cent. The percentage of supporters of building a nuclear power station in 'my city' declined from 23 per cent to 8 per cent, whereas those who were neutral came down from 64 per cent to 38 per cent. In contrast, the fraction of opponents increased from 13 per cent to 54 per cent. The surveys also found that perceived benefits of nuclear power and public trust in government had decreased significantly, whereas knowledge about nuclear power had increased significantly.

Similar studies in other locations also found significant levels of public concern about nuclear safety and reactor accidents (Sun, Zhu, and Meng 2016). China also had the fifth highest difference in the levels of acceptability of nuclear power before and after the Fukushima accident (Kim, Kim, and Kim 2013). More than half of all respondents in one poll felt that only 80 kilometres or more constitutes a safe distance between their homes and a nuclear reactor (He et al. 2014).

Since Fukushima, there has been increasingly prominent opposition to nuclear power plants in China (Buckley 2015; Lok-to 2016). In particular, August 2016 saw the outbreak of large-scale public protests in the city of Lianyungang. Lianyungang was being considered-along with five other sites-as the location for a 100 billion yuan (US $\$ 15$ billion) nuclear reprocessing plant to be built by the CNNC using technology owned by the French company Areva (Green 2016). Thousands of people gathered on the weekend of 6-7 August 2016 to protest against the plant proposal, with protestors making extensive use of Chinese social media platforms such as WeChat to garner further public support (Liu 2016). In addition to their general opposition to nuclear power, protestors drew connections between the Fukushima accident and Lianyungang, arguing that storing radioactive material in a 'seismically active area' like Lianyungang was inappropriate and unsafe (Green 2016: 4). Protestors also cited their frustration with the lack of transparency surrounding the government's decision to site the reprocessing plant in their city. According to reports by the South China Morning Post, local residents only became aware of the plant's possible siting in their city following a press release by the Chinese 
State Administration of Science, Technology and Industry for National Defence (Li 2016). As one resident stated, '[ $t$ ] he government kept the project a secret. People only found out about it recently. That's why most people are worried' (Hornby and Lin 2016).

Despite attempts by the Lianyungang city government to reassure the public that no final decision on the plant's location had been made, protests continued on 8 and 9 August. Subsequently, on 10 August, the Lianyungang city government issued a dramatic turnaround in policy, announcing that it would 'suspend preliminary work on site selection for the nuclear recycling project' ( $\mathrm{Li} 2016$ ). At the same time, Lianyungang authorities also stepped up their efforts to halt the further spread of anti-nuclear protests. At least one individual was arrested for 'allegedly spreading rumours' about a forthcoming protest in Lianyungang, while workers at the Lianyungang Limited Harbor Holding Group-which runs the city's port-were forced to sign an agreement pledging not to 'believe rumours', 'spread rumours', or 'participate' in 'illegal assemblies' (Henochowicz 2016).

The central government also took a direct interest in the Lianyungang situation. On 11 August, central government authorities issued censorship instructions directing media organisations to delete and not republish an article by the Sohu media group entitled 'Cautiously welcoming the decision to suspend the Lianyungang nuclear waste project'. The Sohu article criticised the government's lack of transparency over the nuclear project, described the decision to suspend the project as the 'correct response', and warned the government not to 'underestimate the public's resolve in opposing nuclear waste' (Wade 2016).

The decision to stop the Lianyungang project is not the first cancellation of a proposed nuclear facility in response to public protests. Earlier cancellations include that of the Hongshiding nuclear power plant in Rushan in Shandong province, a nuclear fuel cycle plant in Jiangmen in Guangdong province, and the Hui'an nuclear plant project in Fujian province (Sheng 2014).

What might be more significant than these cancellations for the future of nuclear power in China is that, in September 2016, the Legislative Affairs Office of the State Council issued new draft 'Regulations on Nuclear Power Management' (Hedian guanli tiaoli), which for the first time required nuclear developers to consider public opinion in siting new 
nuclear projects. The announcement of these draft regulations followed shortly after the Lianyungang protests, with the Legislative Affairs Office stating that 'Japan's Fukushima accident once again created doubt about the safety of nuclear power among the public, and also caused feelings of fear and opposition to occur from time to time' (Stanway 2016). Developed by the NDRC and the CNEA, the draft regulations state that developers must work with provincial governments to undertake 'social stability' impact assessments on all new nuclear projects, and must actively seek out public opinion on new projects through public hearings. In addition, the draft regulations stipulate that citizens have the right to public disclosure of government information related to nuclear power (J. Wang 2016; Stanway 2016). Ultimately, the State Council argued, the draft regulations are designed to 'allow the public to participate more actively in the construction and supervision of nuclear projects' (Stanway 2016).

These draft regulations, coupled with the Lianyungang government's decision to cancel the proposed reprocessing plant, demonstrates that public opinion has become a third important constraint on the future development of nuclear power in China. Local and central government authorities in China are now increasingly concerned that growing public opposition to nuclear power could result in the eruption of largescale protests across China. Local and central government authorities have responded to these concerns in part by using the traditional methods of censorship, arrest, and coercion of local labour. But they have also responded by heeding the public's concerns: by suspending the Lianyungang reprocessing plant and by proposing regulations that are designed to increase decision-making transparency and public participation in nuclear power decision-making processes. At the time of writing, it is still too soon to tell whether the Chinese public will actually be granted greater involvement in the decision-making process. However, the swift responses by the Lianyungang city government and the State Council serve as important examples of government sensitivity to public opinion. Given the growth in anti-nuclear sentiment in China since the Fukushima accident, we can expect that public opinion will continue to dampen the push for an expansion of nuclear power in China. 


\section{Conclusion}

The future of nuclear power in China is not what it used to be. A decade ago, China had acquired the reputation of setting very ambitious targets for nuclear power in the country, meeting these targets, and then increasing the targets to even more ambitious heights. That is no longer the case. Because of the changing nature of the economy, the growth rate of energy demand has declined precipitously. The decline has been so sharp and swift that China today has a surplus in electrical generation capacity; consequently, in comparison with previous years, many power plants are being forced to run for fewer hours (as mentioned earlier). Further, due to the inertia in the system, many more power plants, including nuclear plants, are going to come online over the next several years. Thus, the mismatch between electricity demand and availability can be expected to become more severe in the coming years. As a result, a decline in the growth rate of nuclear power can also be expected.

These changes within China also play a part in the efforts by Chinese nuclear operators and reactor constructors to export reactors, with a specific focus on entering markets in Western Europe-for example, Hinkley Point $\mathrm{C}$ in the United Kingdom-by investing large amounts of money. At one level, this can be seen as the maturing of the Chinese nuclear industry and the development of its technical capacity. But, at a different level, this can also be seen as a response to the slowdown in growth in the domestic nuclear market; reactor exports, then, become a route for the continued expansion of reactor construction. However, entering the reactor export marketplace is not easy, and there are many questions about China's ability to supply reactors that perform adequately, especially with regard to safety (Thomas 2017). China also has little experience in executing nuclear projects anywhere except within its own borders. Chinese investment in the Hinkley Point $\mathrm{C}$ reactor is a way to address those concerns and this is being done, in part, by using China's financial clout. There is some expectation that, in exchange, the United Kingdom will allow for the construction of a Chinese reactor down the line at the Bradwell site.

One counter-argument might be that China is also in the process of reducing its reliance on fossil fuels, coal in particular and, as part of that process, it could shut down old coal plants, thus creating a demand for new power plants not based on fossil fuels, such as renewables or nuclear 
power. While this is certainly true, our arguments earlier suggest that the constraints on nuclear power plants-the lengthy time period for construction, the higher costs involved, the problems with imported nuclear reactor designs, and, last but not least, the limited number of coastal sites still available to build nuclear plants—-make it more likely that the replacement for old fossil fuel plants will be renewables-wind and solar-rather than nuclear reactors.

A second counter-argument might be that nuclear energy is considered a baseload source of electricity, whereas solar and wind cannot perform in this fashion. While there are important differences between renewable electricity sources and nuclear power, this argument has less merit now because of the shift in the Chinese economy and the move away from high-energy consuming manufacturing industries-for example, steel or cement. ${ }^{5}$ Industrial energy requirements dominate China's electricity demand pattern.

We do emphasise that our argument is suggestive not definitive. It is certainly possible that there may be a shift in the political balance of power between those who advocate inland reactor construction and those who resist such a push, thereby voiding the siting constraint for new nuclear plants. But the evidence so far makes that scenario seem unlikely. If, prior to the era of low-energy demand growth, advocates of siting reactors away from the coast could not overcome opposition, then it is less likely that they would be able to do so as energy demand growth slows down and as there is local opposition to the siting of nuclear power plants.

The import of these developments and shifts is not that China is moving away from nuclear energy, but neither is it likely to be the powerful engine for global nuclear expansion as had been assumed earlier.

5 The declining importance of baseload electricity generation is testified by many studies in various countries. In Great Britain, for example, one study found that 'with current patterns of electricity demand in GB [Great Britain], the need for baseload vanishes once the GB system secures an average of around 30\% of electricity generated from wind, and 10\% from PV [photovoltaics]' (Smith and Grubb 2016: 3, emphasis in original). 


\section{Acknowledgements}

This chapter is based in part on King and Ramana (2015), but both the structure and the argument have been changed completely. The authors are grateful to Peter Van Ness for his invitation to the 'Nuclear Power in East Asia: The Costs and Benefits' workshop held at The Australian National University, Canberra, 12-14 August 2014, and for his valuable comments on a draft of this chapter. We would also like to thank Wei Peng, Bill Sweet, Stephen Thomas, C. F. Yu, and Derek Abbott for their valuable feedback.

\section{References}

Abe, Tetsuya, 2016. China nuclear industry: State-owned enterprises eye overseas power projects. Nikkei Asian Review, 5 January. asia.nikkei. $\mathrm{com} /$ Business/Deals/State-owned-enterprises-eye-overseas-powerprojects (accessed 23 January 2017).

Aldrich, Daniel P., 2008. Site Fights: Divisive Facilities and Civil Society in Japan and the West. Ithaca, NY: Cornell University Press.

Boccard, Nicolas, 2014. The cost of nuclear electricity: France after Fukushima. Energy Policy 66(March): 450-61. doi.org/10.1016/j. enpol.2013.11.037

Bristow, Michael, 2011. China suspends nuclear building plans. BBC News, 17 March. www.bbc.co.uk/news/world-asia-pacific-12769392 (accessed 31 January 2017).

Buckley, Chris, 2015. China's nuclear vision collides with villagers' fears. New York Times, 21 November.

Chaffee, Phil, 2016. EDF faces British frustrations on Hinkley. Nuclear Intelligence Weekly, 24 March.

Chinadialogue, 2015. New 'ghost cities' typify out-of-control planning. 15 October. www.chinadialogue.net/article/show/single/en/8239-Newghost-cities-typify-out-of-control-planning (accessed 23 January 2017).

China Electricity Council, 2016. Press release, 3 February. www.cec.org. cn/yaowenkuaidi/2016-02-03/148763.html (accessed 2 June 2016). 
CNEA (China National Energy Administration), 2014a. Woguo Hedian Zhuangji Liang 2020nian Mubiao Bubian [No change in China's nuclear installation targets for 2020]. First published in Yicai. com, 20 November. www.china-nea.cn/html/2014-11/31338.html (accessed 23 January 2017).

CNEA (China National Energy Administration), 2014b. Guowuyuan Bangongting Guanyu Yinfa Nengyuan Fazhan Zhanlue Xingdong Jihua (2014nian-2020nian) de Tongzhi [State Council General Office circular concerning the publication of the Energy Development Strategy Action Plan (2014-2020)]. 3 December. www.nea.gov.cn/ 2014-12/03/c_133830458.htm (accessed 23 January 2017).

CNNC (China National Nuclear Corporation), 2016. Sun Qin Daibiao Tan: Zhan Zai Qianyan Lingyu Yinling He Gongye Fazhan [Talks with representative Sun Qin: At the forefront of the development of nuclear industry]. 1 March. www.cnnc.com.cn/publish/portal0/ tab664/info97004.htm (accessed 23 January 2017).

Cui, Zheng, 2012. Ex-officials battle plan to build nuclear plants. Caixin Online, 9 March. www.chinafile.com/reporting-opinion/ caixin-media/ex-officials-battle-plan-build-nuclear-plants (accessed 30 August 2017).

Du, Fenglei, 2010. Site selection for nuclear power plants in China. Presentation to Common Challenges on Site Selection for Nuclear Power Plants. Technical meeting. Vienna: International Atomic Energy Agency, 6-9 July.

Green, Fergus, and Nicholas Stern, 2016. China's changing economy: Implications for its carbon dioxide emissions. Climate Policy 16 March (online): 1-20.

Green, Jim, 2016. Protests against proposed reprocessing plant in China. Nuclear Monitor 829(August): 4-7.

Groden, Claire, 2016. Exxon cuts China energy demand growth forecast. Fortune, 26 January. fortune.com/2016/01/26/china-energy-demand/ (accessed 23 January 2017).

Grubler, Arnulf, 2010. The costs of the French nuclear scale-up: A case of negative learning by doing. Energy Policy 38(9): 5174-88. doi. org/10.1016/j.enpol.2010.05.003 
Hargreaves, Steve, 2012. First new nuclear reactors ok'd in over 30 years. CNNMoney, 9 February. money.cnn.com/2012/02/09/news/ economy/nuclear_reactors/index.htm (accessed 23 January 2017).

He, Guizhen, Arthur P. J. Mol, Lei Zhang, and Yonglong Lu, 2014. Nuclear power in China after Fukushima: Understanding public knowledge, attitudes, and trust. Journal of Risk Research 17(4): 43551. doi.org/10.1080/13669877.2012.726251

He, Zuoxiu, 2013. Chinese nuclear disaster 'highly probable' by 2030. Chinadialogue, 19 March. www.chinadialogue.net/article/show/single/ en/5808-Chinese-nuclear-disaster-highly-probable-by-2-3- (accessed 23 January 2017).

Henochowicz, Anne, 2016. Workers must pledge not to protest nuclear waste plant. China Digital Times, 16 August. chinadigitaltimes. net/2016/08/workers-pressed-pledge-nuclear-waste-plant-protest/ (accessed 23 January 2017).

Hinze, Jonathan, and Yun Zhou, 2012. China's commercial reactors. Nuclear Engineering International, February. belfercenter.ksg.harvard .edu/publication/21789/chinas_commercial_reactors.html?bread

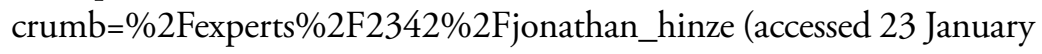
2017).

Hook, Leslie, 2012. China nuclear protest builds steam. Financial Times, 28 February.

Hore-Lacy, Ian, 2014. China's new nuclear baby. World Nuclear News, 2 September. www.world-nuclear-news.org/E-Chinas-new-nuclearbaby-0209141.html (accessed 23 January 2017).

Hornby, Lucy, and Luna Lin, 2016. China protest against nuclear waste plant. Financial Times, 7 August.

$\mathrm{Hu}$, Angang, 2015. Embracing China's 'new normal'. Foreign Affairs, May/June. www.foreignaffairs.com/articles/china/2015-04-20/embracingchinas-new-normal (accessed 23 January 2017). 
Huang, Lei, Ying Zhou, Yuting Han, James K. Hammitt, Jun Bi, and Yang Liu, 2013. Effect of the Fukushima nuclear accident on the risk perception of residents near a nuclear power plant in China. Proceedings of the National Academy of Sciences 110(49): 19742-7. doi. org/10.1073/pnas.1313825110

IEA (International Energy Agency)/NEA (Nuclear Energy Agency), 2010. Projected Costs of Generating Electricity. Paris: Nuclear Energy Agency, OECD.

Kim, Younghwan, Minki Kim, and Wonjoon Kim, 2013. Effect of the Fukushima nuclear disaster on global public acceptance of nuclear energy. Energy Policy 61: 822-8. doi.org/10.1016/j.enpol.2013.06.107

King, Amy, and M. V. Ramana, 2015. The China syndrome? Nuclear power growth and safety after Fukushima. Asian Perspective 39(4): 607-36.

Koomey, Jonathan, and Nathan E. Hultman, 2007. A reactor-level analysis of busbar costs for US nuclear plants, 1970-2005. Energy Policy 35: 5630-42. doi.org/10.1016/j.enpol.2007.06.005

Levi, Michael A., Elizabeth Economy, and Douglas Rediker, 2016. Can the world adjust to China's 'new normal'? World Economic Forum, 10 February. www.weforum.org/agenda/2016/02/can-the-world-adjustto-china-s-new-normal/ (accessed 23 January 2017).

Li, Jing, 2016. Nuclear fuel plant on hold in eastern China after thousands protest. South China Morning Post, 10 August. www.scmp.com/print/ news/china/policies-politics/article/2001726/nuclear-plant-schemehalted-eastern-china-after (accessed 23 January 2017).

Li, Zhen, and Sam Tranum, 2011. Candris says Fukushima will help AP1000 in China. Nuclear Intelligence Weekly, 16 May.

Lin, Jiang, Gang He, and Alexandria Yuan, 2016. Economic rebalancing and electricity demand in China. The Electricity Journal 29(3): 48-54. doi.org/10.1016/j.tej.2016.03.010

Liu, Wen Xin (Cindy), 2016. City suspends nuclear project after thousands protest. China Digital Times, 11 August. chinadigitaltimes. net/2016/08/city-suspends-nuclear-project-thousands-protest/ (accessed 23 January 2017). 
Liu, Yiyu, 2011. New nuclear plants may get green light soon. China Daily, 12 August. www.chinadaily.com.cn/cndy/2011-08/12/content_ 13097545.htm (accessed 23 January 2017).

Lok-to, Wong, 2016. Safety fears cause concern amid delays to China's Taishan nuclear plant. Radio Free Asia, 7 March. www.rfa.org/english/ news/china/safety-03072016114147.html (accessed 23 January 2017).

$\mathrm{Mu}$, Rongping, 2010. China. In UNESCO Science Report 2010: The Current Status of Science Around the World, 379-99. Paris: United Nations Educational, Scientific and Cultural Organization.

$\mathrm{Ng}$, Eric, 2013. China nuclear plant delay raises safety concern. South China Morning Post, 7 October.

Pan, Wang, 2011. China rolls out new homegrown nuclear reactor. Peoplés Daily Online, 18 November. en.people.cn/202936/7649438. html (accessed 23 January 2017).

Ramana, M. V., and Eri Saikawa, 2011. Choosing a standard reactor: International competition and domestic politics in Chinese nuclear policy. Energy 36(12): 6779-89. doi.org/10.1016/j. energy.2011.10.022

Schneider, Mycle, and Antony Froggatt, with Julie Hazemann, Tadahiro Katsuta, M. V. Ramana, and Steve Thomas, 2015. The World Nuclear Industry Status Report 2015. Paris: Mycle Schneider Consulting Project.

Securities Daily [Zhengquan Ribao], 2015. Shanghai Dianli Zhengshi Zhong Dian Tou Jituan Yu Guojia Hedian Jishu Gongsi Jiang Chongzu [Shanghai Electric Power confirms restructure of the CLP [China Power Investment] Group and the National State Nuclear Power Technology Corp]. East Money.com, 3 February. finance.eastmoney.com/news/ 1349,20150203474829119.html (accessed 23 January 2017).

Sheng, Chunhong, 2014. A look at anti-nuclear protests in China. Nuclear Intelligence Weekly, 11 April.

Smith, Andrew Z. P., and Michael Grubb, 2016. Hinkley Point C and other third-generation nuclear in the context of the UK's future energy system. CEE Briefing Note 20160915 AZPS1. London: RCUK Centre for Energy Epidemiology, University College London. 
SNPTC (State Nuclear Power Technology Corporation), 2011. Introduction of State Nuclear Power Technology Corporation. Vol. 2011. 22 January. Beijing: State Nuclear Power Technology Corporation.

Stanway, David, 2009. China struggles to fuel its nuclear energy boom. Reuters, 10 December. www.reuters.com/article/2009/12/10/uraniumchina-nuclear-idUSPEK20761020091210 (accessed 23 January 2017).

Stanway, David, 2014. China says first Westinghouse reactor delayed until at least end-2015. Reuters, 18 July. www.reuters.com/ article/2014/07/18/china-nuclear-ap-idUSL4N0PT0T820140718 (accessed 23 January 2017).

Stanway, David, 2016. China nuclear developers must seek public consent: Draft rules. Reuters, 20 September. www.reuters.com/article/ us-china-nuclear-safety-idUSKCN11Q18K (accessed 23 January 2017).

Sun, Chuanwang, Xiting Zhu, and Xiaochun Meng, 2016. PostFukushima public acceptance on resuming the nuclear power program in China. Renewable and Sustainable Energy Reviews 62: 685-94. doi. org/10.1016/j.rser.2016.05.041

Taishan Nuclear Power Joint Venture Co., 2016. Taishan Unit 1 CFT completed successfully. 1 February. en.tnpjvc.com.cn/n1623/n1624/ c1235803/content.html (accessed 23 January 2017).

Thibault, Harold, 2010. Construction schedule on Chinese thirdgeneration nuclear plants races ahead of European models. Guardian, 28 December.

Thomas, Steve, 2017. China's nuclear export drive: Trojan Horse or Marshall Plan? Energy Policy 101: 683-91. doi.org/10.1016/j. enpol.2016.09.038

US NRC (Nuclear Regulatory Commission), 2011. AP1000 Design Certification Amendment. Federal Register, 30 December. www. federalregister.gov/articles/2011/12/30/2011-33266/ap1000-designcertification-amendment\#h-13 (accessed 23 January 2017).

Wade, Samuel, 2016. Minitrue: Delete article on nuclear project suspension. China Digital Times, 11 August. chinadigitaltimes.net/ 2016/08/minitrue-delete-article-lianyungang-nuclear-suspension/ (accessed 23 January 2017). 
Wang, Jiayuan, 2016. Liang Bumen Ni Guiding: Hedianchang Xuanzhi Deng Shixiang Ying Zhengqiu Gongzhong Yijiang [Two departments draft rules: Must seek public opinion on nuclear power plant site selection]. Sina, 19 September. finance.sina.com.cn/china/2016-09-19/ doc-ifxvyqwa3505314.shtml (accessed 23 January 2017).

Wang, Lu, 2016. Neilu Fazhan Hedian Yuqi Shengwen Nengyuan Ju Huiying: Chongqi Wu Shijian Biao [Inland nuclear power development expected to heat up energy agency response: No restart schedule]. Jingji Cankao Bao [Economic Information Daily], 7 March. news.xinhuanet.com/fortune/2016-03/07/c_128778398.htm (accessed 23 January 2017).

Wang, Qiang, 2009. China needing a cautious approach to nuclear power strategy. Energy Policy 37(7): 2487-91. doi.org/10.1016/j. enpol.2009.03.033

Wen, Bo, 2014. Inland provinces: Nuclear at crossroads. China Water Risk, 13 August. chinawaterrisk.org/opinions/inland-provincesnuclear-power-at-crossroads/ (accessed 23 January 2017).

Wen, Jiabao, 2012. Wen Jiabao Zhuchi Zhaokai Guowuyuan Changwu Huiyi [Wen Jiabao chairs executive meeting of the State Council]. Central People's Government of the People's Republic of China website, 24 October. www.gov.cn/ldhd/2012-10/24/content_2250357. htm (accessed 23 January 2017).

Westinghouse Electric Company, 2000. Westinghouse AP600 receives design certification from US NRC; Company to aggressively market advanced/passive reactor throughout the world; Technology offers improved safety features. health.phys.iit.edu/extended_archive/0001/ msg00154.html (accessed 4 September 2017).

WNA (World Nuclear Association), 2010. Nuclear power in China. London: World Nuclear Association.

WNA (World Nuclear Association), 2011. Nuclear power in China. London: World Nuclear Association.

Wong, Kimfeng, 2016a. Coal loses more market share to nuclear, renewables. Nuclear Intelligence Weekly, 19 February.

Wong, Kimfeng, 2016b. A radical solution to loosen coal's grip. Nuclear Intelligence Weekly, 5 August. 
World Nuclear News, 2010. China prepares to export reactors. 25 November.

World Nuclear News, 2015. Hualong One selected for Argentina. 5 February.

World Nuclear News, 2016. Hualong One joint venture officially launched. 17 March.

World Nuclear News, 2017. Construction milestones at new Chinese units.

5 January. www.world-nuclear-news.org/NN-Construction-milestonesat-new-Chinese-units-0501175.html (accessed 6 February 2017).

Xie, Wei, 2016. Guojia Dian Tou Dongshi Zhang Wang Binghua: Neilu Hedian Yao Jian, Dan Yao Bawo Shiji [State Power Investment Chairman Wang Binghua: We must build inland nuclear power, but we must grasp the opportune moment]. Zhongguo Jingji Zhoukan [China Economic Weekly], 14 March. www.ceweekly.cn/2016/0314/144250. shtml (accessed 23 January 2017).

Xinhua, 2011. China not to change plan for nuclear power projects: Government. 12 March. news.xinhuanet.com/english2010/china/201103/12/c_13774519.htm (accessed 31 January 2017).

Xinhua, 2014. CGN invests $\$ 6 \mathrm{~b}$ on nuclear power in Guizhou. China Daily, 14 July. www.chinadaily.com.cn/china/2014-07/11/ content_17736464.htm (accessed 23 January 2017).

Xinhua, 2016. China sets energy use target for 2016. 1 April. news.xinhuanet.com/english/2016-04/01/c_135244392.htm (accessed 23 January 2017).

$\mathrm{Xu}$, Yi-Chong, 2008. Nuclear energy in China: Contested regimes. Energy 33(8): 1197-205. doi.org/10.1016/j.energy.2008.03.006

$\mathrm{Xu}$, Yi-Chong, 2014. The struggle for safe nuclear expansion in China. Energy Policy 73: 21-9. doi.org/10.1016/j.enpol.2014.05.045

Xuyang, Jingjing, 2012. Not in my backyard. Global Times, 17 February. en.people.cn/90882/7731890.html (accessed 23 January 2017).

Yap, Chuin-Wei, and Brian Spegele, 2015. China's first advanced nuclear reactor faces more delays. Wall Street Journal, 15 January. 
Ying, Li, 2016. China's power sector and the economic 'new normal'. Chinadialogue, 25 January. www.chinadialogue.net/article/show/ single/en/8558-China-s-power-sector-and-the-economic-new-normal(accessed 23 January 2017).

Yu, C. F., 2015. Inland nuclear developers await policy change. Nuclear Intelligence Weekly, 2 January.

Yu, C. F., 2016a. CNNC and CGN launch Hualong JV. Nuclear Intelligence Weekly, 8 January.

Yu, C. F., 2016b. Construction on inland plants unlikely before 2020 . Nuclear Intelligence Weekly, 1 April.

Yuan, Jiahai, Peng Li, Yang Wang, Qian Liu, Xinyi Shen, Kai Zhang, and Liansai Dong, 2016. Coal power overcapacity and investment bubble in China during 2015-2020. Energy Policy 97: 136-44. doi. org/10.1016/j.enpol.2016.07.009

Zheng, Xiaoyi, and Qi Wu, 2010. China advances in independently tapping nuclear power. Xinhua, 18 February. old.csr-china.net/en/ second.aspx?nodeid=ddd0b45c-b7c4-4947-b2e3-e20374708733\&pa ge $=$ contentpage $\&$ contentid $=23$ c48153-ebb7-4af5-855e-fff6e8ec $4 b 67$ (accessed 11 September 2017).

Zhongguo Hedian Wang, 2015. Hunan, Hubei Huyu Chongqi Neilu Hedian Xiangmu Anquan Xing Rengyou Zhengyi [Hunan, Hubei call for the restarting of inland nuclear power projects - Safety still controversial]. ChinaPower.com, 16 March. np.chinapower.com.cn/ 201503/16/0044739.html (accessed 23 January 2017).

Zhongguo Jinggong Bao, 2014. Xiang E Gan Li Tui Hedian Neilu 'shou He' 2016 Nian Huo Kaizha' [Hunan Hubei Jiangxi push to open the 'first nuclear' inland power station, probably in 2016]. 9 September. www.heneng.net.cn/index.php? $\bmod =$ news\&action $=$ show\&article_ id=31982\&category_id=9 (accessed 23 January 2017).

Zhou, Sheng, and Xiliang Zhang, 2010. Nuclear energy development in China: A study of opportunities and challenges. Energy 35(11): 4282-8. doi.org/10.1016/j.energy.2009.04.020 
Zhou, Yun, 2012. China's nuclear energy industry, one year after Fukushima. Policy Brief, Belfer Center's Technology and Policy Blog, 5 March.

Zhu, Yue, 2014. China's nuclear expansion threatened by public unease. Chinadialogue, 23 September. www.chinadialogue.net/article/show/ single/en/7336-Chinese-protesters-threaten-nuclear-expansion (accessed 23 January 2017). 
This text is taken from Learning from Fukushima: Nuclear power in East Asia, edited by Peter Van Ness and Mel Gurtov, published 2017 by ANU Press, The Australian National University, Canberra, Australia.

dx.doi.org/10.22459/LF.09.2017.04 